\title{
Spiroplasma montanense sp. nov., from Hybomitra Horseflies at Northern Latitudes in North America
}

\author{
ROBERT F. WHITCOMB, ${ }^{1 *}$ FRANK E. FRENCH, ${ }^{2}$ JOSEPH G. TULLY, ${ }^{3}$ DAVID L. ROSE ${ }^{3}$ \\ PATRICIA M. CARLE, ${ }^{4}$ JOSEPH M. BOVE, ${ }^{4}$ EDWARD A. CLARK, ${ }^{5}$ ROBERTA B. HENEGAR, ${ }^{1}$ \\ MEGHNAD KONAI, ${ }^{5}$ KEVIN J. HACKETT, ${ }^{5}$ JEAN R. ADAMS, ${ }^{5}$ \\ AND DAVID L. WILLIAMSON ${ }^{6}$
}

Vegetable Laboratory, ${ }^{1}$ and Insect Biocontrol Laboratory, ${ }^{5}$ U.S. Department of Agriculture, Beltsville, Maryland 20705; Department of Biology, Georgia Southern University, Statesboro, Georgia 30460²; Mycoplasma Section, Laboratory of Molecular Microbiology, National Institute of Allergy and Infectious Diseases, Frederick Cancer Research Facility, Frederick, Maryland 21701 ${ }^{3}$; Laboratoire de Biologie Cellulaire et Moléculaire, Institut

Nationale de Recherche Agronomique, Villenave d'Ornon, France ${ }^{4}$; and Department of Anatomical Sciences, State University of New York, Stony Brook, New York $11794^{6}$

\begin{abstract}
Spiroplasma strain HYOS-1 ${ }^{\mathrm{T}}$ was isolated from a tabanid fly, Hybomitra opaca. The organism was serologically distinct from other spiroplasma species, groups, and subgroups and was recently designated the representative of spiroplasma group XXXI. The cells of strain HYOS $-1^{\mathrm{T}}$, as determined by light microscopy, were long motile helices. Electron microscopic examination revealed wall-less cells delimited by a single membrane. The cells passed through $450-$ and 300-nm filter pores with a 10-fold reduction in titer, but failed to pass through 100-nm pores. Strain HYOS-1 ${ }^{\mathrm{T}}$ grew very well in most conventional medium formulations for spiroplasmas or other mollicutes. The organism grew at temperatures ranging from 5 to $41^{\circ} \mathrm{C}$, and the optimum temperature was $32^{\circ} \mathrm{C}$. The doubling time at the optimum temperature was $0.7 \mathrm{~h}$, one of the shortest values obtained for members of the genus Spiroplasma. The strain catabolized glucose and hydrolyzed arginine but not urea. Growth of the organism was stimulated by cholesterol and serum, but the strain was nevertheless able to grow in the absence of sterols or serum. The guanine-plus-cytosine content of the DNA was about $28 \pm 1$ mol\%, and the genome size was $1,225 \mathrm{kbp}$. On the basis of the experimental results reported here and previously reported data, group XXXI strain HYOS-1 (= ATCC 51745) is designated the type strain of a new species, Spiroplasma montanense.
\end{abstract}

Thirteen spiroplasma groups, putative groups, or subgroups are associated with tabanid flies $(5,8-10,34,36)$. The following species or unnamed strains appear to occur primarily in tabanid hosts: some group IV strains (Spiroplasma apis); representatives of three group VIII subgroups (11), including subgroup VIII-1 strain EA-1 ${ }^{\mathrm{T}}$ (Spiroplasma syrphidicola) (35), subgroup VIII-2 strain DF-1 ${ }^{\mathrm{T}}$ (Spiroplasma chrysopicola) (34), and subgroup VIII-3 strain TAAS-1 (= ATCC 51123); strains related to EC-1 ${ }^{\mathrm{T}}$ (group XIV; Spiroplasma corruscae) (14); strain TN-1 ${ }^{\mathrm{T}}$ (group XVIII; Spiroplasma litorale) (19); strain TG-1 ${ }^{\mathrm{T}}$ (group XXIII; Spiroplasma gladiatoris) (34); group XXVII strain TALS-2 (37); strain TABS-2 ${ }^{\mathrm{T}}$ (group XXXII; Spiroplasmahelicoides) (34); strain TAUS- $1^{\mathrm{T}}$ (group XXXIII; Spiroplasma tabanidicola) (34); and representatives of two putative groups, strains B1901 and B2649. In this paper we describe strain HYOS $-1^{\mathrm{T}}$, a representative of group XXXI of spiroplasmas found in tabanid flies, including several species of the genus Hybomitra. S. litorale was the first tabanid spiroplasma shown to have a geographically limited distribution; this organism is confined essentially to the southeast Atlantic coastal plain in the United States (19). Strain HYOS- $1^{\mathrm{T}}$ is also geographically limited since it has been isolated only from northern latitudes. Our characterization studies established that strain HYOS-1 can be considered the type strain of a new species. In this paper we designate strain HYOS-1 (= ATCC $51745)$ the type strain of Spiroplasma montanense sp. nov.

* Corresponding author. Mailing address: Vegetable Laboratory, HH3, Range 2, BARCW, Beltsville, MD 20705. Phone: (301) 5048339. Fax: (301) 504-6017.

\section{MATERIALS AND METHODS}

Spiroplasma strains. Strain HYOS $-1^{\mathrm{T}}$ was isolated by previously described techniques $(5,21)$ from the gut of a tabanid fly (Hybomitra opaca) collected in Livingston, Mont., by R. F. Whitcomb and E. A. Clark. Strain HYOS-1 ${ }^{\mathrm{T}}$ was purified by conventional filtration-cloning techniques (25). Representative strains of all previously recognized spiroplasma groups and subgroups (28-30, 37, 40 ), including the type strains of all previously recognized species, were also employed in this study.

Culture medium and cultivation techniques. The isolate from which strain HYOS-1 ${ }^{\mathrm{T}}$ was derived was grown in primary culture in M1D liquid medium containing $500 \mathrm{U}$ of penicillin per $\mathrm{ml}(33)$ at $30^{\circ} \mathrm{C}$. After several early broth passages, the isolate was lyophilized. For characterization, the dried culture was revived and cloned (25) in M1D broth at $30^{\circ} \mathrm{C}$. Strain HYOS-1 ${ }^{\mathrm{T}}$ also grew wel in other medium formulations, including SP-4 medium, conventional mycoplasma medium containing bovine or horse serum, and $1 \%$ bovine serum fraction medium (32). Solid medium was prepared by adding Noble agar (Difco Laboratories, Detroit, Mich.) to a final concentration of $2.25 \%$. Agar cultures were incubated at room temperature $\left(21^{\circ} \mathrm{C}\right)$ and at $30^{\circ} \mathrm{C}$ either aerobically or anaerobically in a GasPak system (BBL Microbiology Systems, Cockeysville, Md.) Temperature requirements for growth were assessed as described previously, with growth measured at temperatures ranging from 5 to $43^{\circ} \mathrm{C}(18,19)$.

Morphological studies. Cells of strain HYOS $-1^{\mathrm{T}}$ cultivated in M1D broth to the logarithmic phase were examined by dark-field microscopy at a magnification of $\times 1,250$. An electron microscopic examination of the membrane structure of strain HYOS $-1^{\mathrm{T}}$ was performed by using previously described techniques (38).

Tests for biological and biochemical properties. The procedures used to study carbohydrate fermentation and arginine and urea hydrolysis have been described previously (1). Filtration characteristics were determined in M1D broth by passing logarithmic-phase cultures through filters with 450-, 300-, 220-, and 100-nm pores. Each filtrate, as well as an unfiltered control, was subcultured in a series of 12 tubes by using 10 -fold dilutions and was monitored to determine growth at $30^{\circ} \mathrm{C}(25)$

Sterol requirement. Sterol requirements for growth were determined by two methods. The cell protein yields of strain HYOS $-1^{\mathrm{T}}$ grown in serum-free broth media containing various concentrations of cholesterol were determined, and the ability of the organism to continue to grow in various serum-free or serumcontaining medium formulations was also studied $(24,26)$.

Serological tests. Antiserum to strain HYOS $-1^{\mathrm{T}}$ was produced in rabbits as described previously (41). Hyperimmune antisera to all previously established 


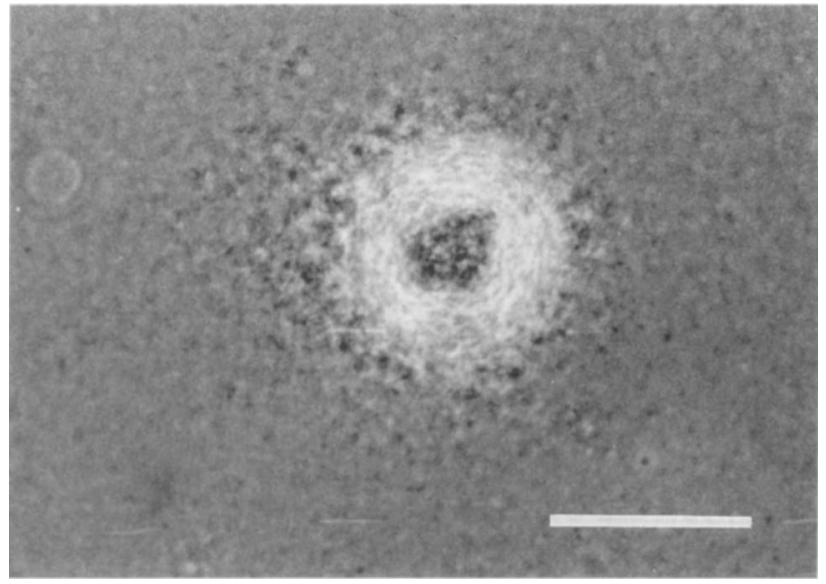

FIG. 1. Colonies of strain HYOS $-1^{\mathrm{T}}$ on SP-4 medium supplemented with $2.25 \%$ Noble agar after 3 days of incubation at room temperature $\left(21^{\circ} \mathrm{C}\right)$ under aerobic conditions. Bar $=50 \mu \mathrm{m}$.

Spiroplasma species, groups, putative groups, and subgroups $(28-30,37,40)$ were obtained from the reference collections at the Beltsville Agricultural Research Center and the National Institute of Allergy and Infectious Diseases laboratory in Frederick, Md. Strain HYOS-1 ${ }^{\mathrm{T}}$, the antisera, and the other strains were tested reciprocally by performing metabolism inhibition and deformation tests as previously described $(39,41)$. Reciprocal crosses in both of these tests are required to reliably establish serological relationships among spiroplasmas.

Genomic analysis. The techniques used for extraction and purification of mollicute chromosomal DNA have been described previously (3). The guanineplus-cytosine content of purified DNA of strain HYOS-1 ${ }^{\mathrm{T}}$ was determined by the buoyant density method (4). The genome size was determined by pulsed-field gel electrophoresis, as described previously (3).

\section{RESULTS AND DISCUSSION}

Cultural and morphological properties. Strain HYOS $-1^{\mathbf{T}}$ grew well in M1D and SP-4 media, in conventional mycoplasma media containing horse serum (Edward formulation) or fetal bovine serum, and in bovine serum fraction medium. The organism grew in the presence of $500 \mathrm{U}$ of penicillin per $\mathrm{ml}$. Strain HYOS $-1^{\mathrm{T}}$ grew at temperatures between 5 and $41^{\circ} \mathrm{C}$, and optimum growth occurred at $32^{\circ} \mathrm{C}(17,18)$. The doubling time at the optimum temperature in M1D broth was $0.7 \mathrm{~h}$. Perceptible but nonquantifiable growth occurred at $41^{\circ} \mathrm{C}$. Colonies of strain HYOS $-1^{\mathrm{T}}$ on solid SP-4 medium supplemented with $2.25 \%$ agar at room temperature under aerobic conditions appeared to be granular and to have dense centers, irregular margins, and numerous small satellites (Fig. 1). "Fried-egg" colonies were never observed.

Logarithmic-phase cultures of strain HYOS-1 ${ }^{\mathrm{T}}$ in M1D medium were examined by dark-field microscopy, and these cultures contained numerous long motile filaments. The cells of the organism sedimented from broth cultures and examined by electron microscopy were filamentous with no evidence of a cell wall (Fig. 2); instead, they were surrounded by a single cytoplasmic membrane.

Sterol requirement. The growth responses of strain HYOS$1^{\mathrm{T}}$ (as measured by total cell protein) when cholesterol was added to serum-free SP-4 medium are shown in Table 1 . The results of this test indicated that growth of the strain was stimulated by cholesterol. However, in the test described by Rose et al. (24), in which the ability of strain HYOS $-1^{\mathrm{T}}$ to continue to grow in serum-free or serum-containing media was examined, the organism grew through 23 serial 10 -fold dilutions in serum-free medium devoid of sterols. Addition of $0.04 \%$ polyoxyethylene sorbitan (Tween 80 ) to the serum-free

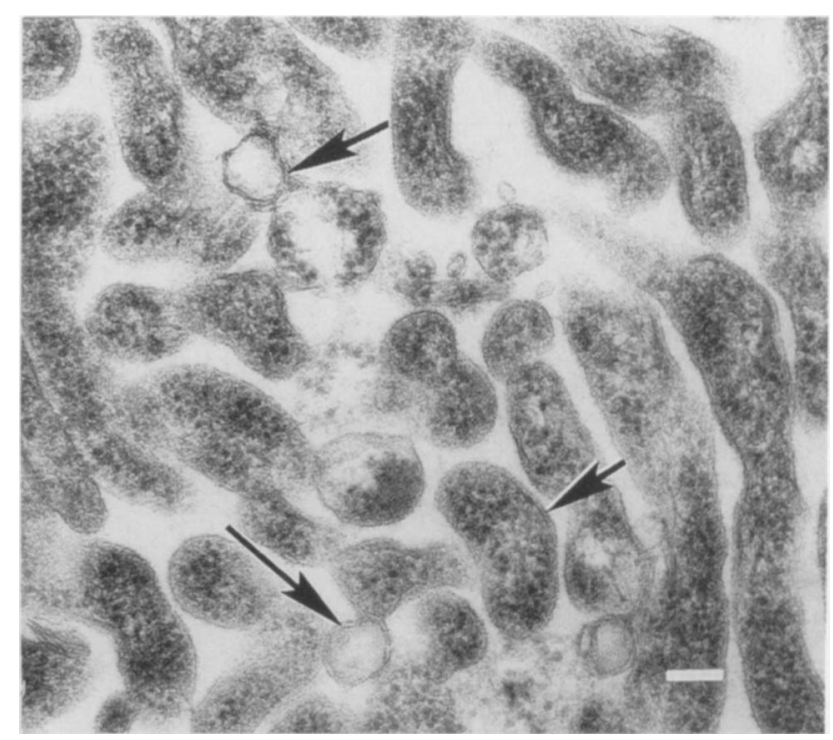

FIG. 2. Electron micrograph of a thin section of pelleted cells of strain HYOS $-1^{\mathbf{T}}$. The arrows indicate the single trilaminar plasma membrane. Bar $=$ $100 \mathrm{~nm}$.

formulation did not support sustained growth of strain HYOS$1^{\mathrm{T}}$. The latter findings indicate that strain HYOS $-1^{\mathrm{T}}$ does not have a growth requirement for cholesterol. The strain therefore resembles several other spiroplasmas (24) in its ability to grow in sterol-free media.

Biochemical and biological properties. Strain HYOS $-1^{\mathrm{T}}$ produced acid from glucose and hydrolyzed arginine, but was negative for urea hydrolysis. Passage of broth cultures of strain HYOS $-1^{\mathrm{T}}$ through 450 - and 300 -nm-pore-size membrane filters reduced the viable cell titer 10 -fold. No cells passed through 100-nm-pore-size filters.

Serological tests. The results of metabolism inhibition and spiroplasma deformation tests performed with antisera prepared to known spiroplasma species, groups, and subgroups (Table 2) indicated that strain HYOS $-1^{\mathrm{T}}$ was serologically unrelated to representatives of previously established Spiroplasma groups or species. Low-level heterologous one-way crossreactions were observed with several groups, but such reactions are not significant for assessing serological relationships.

Genome size and DNA base composition. The genome size of strain HYOS-1 ${ }^{\mathrm{T}}$ was $1,225 \mathrm{kbp}(3)$, and the base composition (guanine-plus-cytosine content) of the DNA was $28 \pm 1$ mol\%.

TABLE 1. Growth response of strain HYOS $-1^{\mathrm{T}}$ to cholesterol

\begin{tabular}{llc}
\hline \multicolumn{1}{c}{ Medium } & $\begin{array}{c}\text { Cholesterol concn } \\
(\mu \mathrm{g} / \mathrm{ml})\end{array}$ & $\begin{array}{c}\text { Amt of protein } \\
(\mathrm{mg} / 100 \mathrm{ml})^{a}\end{array}$ \\
\hline M1D medium & 0 (control) & 3.08 \\
Base medium with no supplement & 0 & 0.02 \\
Base medium with serum fraction & 0 (control) & 3.16 \\
Base medium with cholesterol & 1 & 0.31 \\
& 2 & 0.72 \\
& 5 & 2.16 \\
& 10 & 2.92 \\
& 20 & 2.50 \\
\hline
\end{tabular}

$a$ The amount of cell protein was determined from a cell pellet obtained from $100 \mathrm{ml}$ of each culture medium. 
TABLE 2. Serological reactions and cross-reactions of strain HYOS $-1^{\mathrm{T}}$ in deformation and metabolism inhibition serological tests ${ }^{a}$

\begin{tabular}{|c|c|c|c|c|c|}
\hline \multirow{3}{*}{ Group } & \multirow{3}{*}{ Strain } & \multicolumn{4}{|c|}{ Titer in: } \\
\hline & & \multicolumn{2}{|c|}{$\begin{array}{l}\text { Spiroplasma defor- } \\
\text { mation test }\end{array}$} & \multicolumn{2}{|c|}{$\begin{array}{l}\text { Metabolism } \\
\text { inhibition test }\end{array}$} \\
\hline & & Antiserum & Antigen & Antiserum & Antigen \\
\hline $\mathrm{I}-4$ & $277 \mathrm{~F}$ & $0^{b}$ & $0^{c}$ & $486^{d}$ & $0^{e}$ \\
\hline $\mathrm{I}-5$ & LB-12 & 0 & 0 & 18 & 0 \\
\hline $\mathrm{I}-8$ & $\mathrm{P} 40^{\mathrm{T}}$ & 20 & 0 & 0 & 0 \\
\hline II & DW-1 & 0 & 0 & 54 & 0 \\
\hline IV & $\mathrm{B} 31^{\mathrm{T}}$ & 40 & 0 & 0 & 0 \\
\hline VII & MQ- $1^{\mathrm{T}}$ & 0 & 0 & 18 & 0 \\
\hline VIII-3 & TAAS-1 & 40 & 0 & 0 & 0 \\
\hline XIV & $\mathrm{EC}-1^{\mathrm{T}}$ & 0 & 20 & 0 & 0 \\
\hline XVI-1 & $C C-1^{T}$ & 0 & $20(2,560)^{f}$ & 0 & 0 \\
\hline XVI-2 & CB-1 & 0 & 0 & 0 & $18(39,000)^{f}$ \\
\hline XIX & PUP-1 ${ }^{\mathrm{T}}$ & 0 & 0 & 54 & 0 \\
\hline $\mathrm{XX}$ & LD $-1^{T}$ & 0 & 0 & 486 & 0 \\
\hline XXIII & TG-1 ${ }^{\mathrm{T}}$ & 20 & 0 & 0 & 0 \\
\hline XXV & CUAS- $1^{T}$ & 40 & 0 & 0 & 0 \\
\hline XXVI & PLHS-1 ${ }^{\mathrm{T}}$ & 40 & 0 & 162 & 0 \\
\hline XXXI & HYOS-1 $1^{\mathrm{T}}$ & $5,120^{g}$ & 5,120 & $117,000^{g}$ & 117,000 \\
\hline XXXII & TABS- $2^{\mathrm{T}}$ & 0 & $40(640)^{f}$ & 0 & 0 \\
\hline
\end{tabular}

${ }^{a}$ Antigens and antisera of the strains were tested in all combinations against all known and putative groups and subgroups. All cross-reactions except those shown were negative.

${ }^{b}$ Reciprocal of the endpoint in a deformation test in which the antigen was tested against antiserum against strain HYOS-1 ${ }^{\mathrm{T}}$.

${ }^{c}$ Reciprocal of the endpoint in a deformation test in which the antiserum was tested against strain HYOS- $1^{\mathrm{T}}$ antigen.

${ }^{d}$ Reciprocal of the endpoint in a metabolism inhibition test in which the antigen was tested against antiserum against strain HYOS- $1^{\mathrm{T}}$.

${ }^{e}$ Reciprocal of the endpoint in a metabolism inhibition test in which the antiserum was tested against strain HYOS- $1^{\mathrm{T}}$ antigen.

${ }^{f}$ The value in parentheses is the reciprocal of the endpoint obtained with the homologous antiserum against which strain HYOS $-1^{\mathrm{T}}$ antigen was tested.

${ }^{g}$ Homologous titer of the strain in the test system. The reaction, obtained only once, is shown for completeness.

Habitat. The single strain described here was isolated directly from the abdominal viscera of a tabanid fly $(H$. opaca) from Livingston, Mont. Isolates related to this strain have been obtained from four other Hybomitra spp. (Hybomitra affinis, Hybomitra epistates, Hybomitra lasiophthalma, and Hybomitra nitidifrons). All isolates obtained from Hybomitra spp. that are referable to $S$. montanense were derived from flies captured north of $38^{\circ} 30^{\prime} \mathrm{N}$ latitude. In addition to the original isolate, we have seven isolates from Nova Scotia, Canada, and one isolate from Vermont. Several strains from Connecticut tabanids (1a) have been found to be related to strain HYOS-1 ${ }^{\mathrm{T}}$, and isolates have been obtained from deerflies (Chrysops sp.) in West Virginia (33).

A cluster of isolates from Georgia tabanids (Hybomitra difficilus and Chrysops brimleyi) which are active during the spring reacted significantly in one-way deformation tests with antisera against strain $\mathrm{HYOS}-1^{\mathrm{T}}$, but also reacted significantly with antisera against group IV strains $\mathrm{B} 31^{\mathrm{T}}$ and $\mathrm{W} 13$. Another cluster of Georgia isolates reacted significantly with strain HYOS $-1^{\mathrm{T}}$ and the group XIV strain $S$. corruscae EC- $1^{\mathrm{T}}$. The relationship between strain HYOS- $1^{\mathrm{T}}$ and these southern strains should be studied further by performing reciprocal serological studies or, perhaps, by sequencing the $16 \mathrm{~S}$ ribosomal DNA gene.

Spiroplasmas are especially interesting as models of the ecological interaction between microbes and insects (13). Strain HYOS $-1^{\mathrm{T}}$ has been used as a model organism by F. E. French's group. A variety of tabanids have been infected by feeding them sugar water containing strain $\operatorname{HYOS}-1^{\mathrm{T}}(2,6-8,15,20$, 23). The bacterium has been recovered after laboratory feeding from one Hybomitra species, three Chrysops species, and eight Tabanus species. The population sizes established in tabanid guts ranged from $10^{4}$ to $10^{6}$ color-changing units per gut (20). Horizontal transfer occurred from orally infected flies that were in the same glass jar (8). The longevity of tabanids in the laboratory was not affected by the presence of strain HYOS $-1^{\mathrm{T}}$ in the flies $(6,8)$. Injected Tenebrio molitor (Coleoptera: Tenebrionidae) mealworm pupae carried the infection through metamorphosis, and the strain could be cultured from the guts of adult beetles $(7,12)$. Strain HYOS $-1^{\mathrm{T}}$ survives for up to 180 days in air-dried droplets maintained at room temperature $(22,31)$. These experimental results provide important insights into the dynamics of spiroplasma maintenance in holometabolous insects.

Classification of strain HYOS-1 ${ }^{\mathbf{T}}$. The properties of strain HYOS $-1^{\mathrm{T}}$ described below fulfill the following proposed criteria (16) for descriptions of species of the class Mollicutes: absence of a cell wall, filterability, lack of reversion to walled bacteria when the organism is grown in antibiotic-free media, and penicillin resistance. The growth requirements, the inability to utilize urea, and the helicity and motility of strain HYOS $-1^{\mathrm{T}}$ place the organism in the order Entomoplasmatales and the family Spiroplasmataceae (27). Finally, the results of a serological comparison of strain HYOS $-1^{\mathrm{T}}$ to other Spiroplas$m a$ species, groups, and subgroups demonstrated the uniqueness of this new insect strain. We therefore propose the name Spiroplasma montanense for this organism. The taxonomic description below summarizes the properties of this species.

Description of Spiroplasma montanense sp. nov. Spiroplasma montanense (mon.ta.nen'se. M.L. adj. montanense, pertaining to Montana, where the species was first isolated).

Cells are helical, motile filaments that lack a cell wall. Colonies on solid medium containing $2.25 \%$ Noble agar are granular and have dense centers, irregular margins, and numerous small satellites.

Chemoorganotroph. Acid is produced from glucose. Hydrolyzes arginine but not urea.

Cholesterol or serum is not required for growth.

The temperature range for growth is 5 to $41^{\circ} \mathrm{C}$, and optimum growth occurs at $32^{\circ} \mathrm{C}$; at $32^{\circ} \mathrm{C}$ the doubling time is $0.7 \mathrm{~h}$.

Serologically distinct from previously established Spiroplasma species, groups, and subgroups. Isolated from the gut of the tabanid fly $H$. opaca. Pathogenicity for insects has not been determined.

The guanine-plus-cytosine content of the DNA is $28 \pm 1$ mol\%, as determined by the buoyant density method. The genome size is approximately $1,225 \mathrm{kbp}$.

The type strain is HYOS-1 (= ATCC 51745).

\section{ACKNOWLEDGMENT}

We thank Hans G. Trüper for his advice concerning the specific epithet.

\section{REFERENCES}

1. Aluotto, B. B., R. G. Wittler, C. O. Williams, and J. E. Faber. 1970. Standardized bacteriologic techniques for characterization of Mycoplasma species. Int. J. Syst. Bacteriol. 20:35-58.

1a.Anderson, J. Personal communication.

2. Burnett, V. P., and F. E. French. 1996. Laboratory transfer of Spiroplasma to tabanid flies. Assoc. Southeast. Biol. Bull. 43:113.

3. Carle, P., F. Laigret, J. M. Bové, and J. G. Tully. 1995. Heterogeneity of genome size measurements of the genus Spiroplasma. Int. J. Syst. Bacteriol. 45:178-181.

4. Carle, P., C. Saillard, and J. M. Bové. 1983. Determination of guanine plus cytosine content of DNA. Methods Mycoplasmol. 1:301-308. 
5. Clark, T. B., R. V. Peterson, R. F. Whitcomb, R. B. Henegar, K. J. Hackett, and J. G. Tully. 1984. Spiroplasmas in the Tabanidae. Isr. J. Med. Sci. 20:1002-1005.

6. Deal, N. E., and F. E. French. 1991. Laboratory transfer and June-July incidence of Spiroplasma (Mollicutes) in tabanids (Diptera: Tabanidae) of Bulloch Co., Georgia. Ga. J. Sci. 49:24.

7. French, F. E., J. Wedincamp, J. M. Harper-Punjabi, J. C. Gravitt, R. B. Henegar, and R. F. Whitcomb. 1994. Laboratory infection of Tabanidae (Diptera) with tabanid-associated spiroplasma and carriage in Tenebrio (Coleoptera) and Sarcophaga (Diptera). IOM Lett. 3:533-534.

8. French, F. E., R. F. Whitcomb, D. V. Hagan, J. A. Raftner, M. Konai, and E. A. Clark. 1992. Dynamics of spiroplasma infections in tabanid (Diptera: Tabanidae) files. IOM Lett. 2:114.

9. French, F. E., R. F. Whitcomb, J. G. Tully, K. J. Hackett, E. A. Clark, R. B. Henegar, and D. L. Rose. 1990. Tabanid spiroplasmas of the southeast USA: new groups and correlation with host life history strategy. Zentralbl. Bakteriol. Suppl. 20:919-921.

10. French, F. E., R. F. Whitcomb, D. L. Williamson, and R. B. Henegar. 1996. Spiroplasmas of Tabanus lineola. IOM Lett. 4:211-212.

11. Gasparich, G. E., C. Saillard, E. A. Clark, M. Konai, F. E. French, J. G. Tully, K. J. Hackett, and R. F. Whitcomb. 1993. Serologic and genomic relatedness of group VIII and group XVII and subdivision of spiroplasma group VIII into subgroups. Int. J. Syst. Bacteriol. 43:338-341.

12. Gravitt, J. C., and F. E. French. 1994. Carriage of Spiroplasma (Mycoplasmatales) associated with Tabanidae in Coleoptera and other Diptera. Ga. J. Sci. 52:27.

13. Hackett, K. J., and T. B. Clark. 1989. The ecology of spiroplasmas, p. 113-200. In R. F. Whitcomb and J. G. Tully (ed.), The mycoplasmas, vol. 5. Academic Press, Inc., New York, N.Y.

14. Hackett, K. J., R. F. Whitcomb, F. E. French, J. G. Tully, G. E. Gasparich, D. L. Rose, P. Carle, J. M. Bové, R. B. Henegar, T. B. Clark, M. Konai, E. A. Clark, and D. L. Williamson. 1996. Spiroplasma corruscae sp. nov., a new species from a firefly beetle (Coleoptera: Lampyridae) and tabanid flies (Diptera: Tabanidae). Int. J. Syst. Bacteriol. 46:947-950.

15. Harper, J. M., and F. E. French. 1994. Oral transmission of Spiroplasma strain HYOS-1 (Mollicutes: Mycoplasmatales) to Tabanidae. Ga. J. Sci. 52:27.

16. International Committee on Systematic Bacteriology Subcommittee on the Taxonomy of Mollicutes. 1995. Revised minimal standards for descriptions of new species of the class Mollicutes (division Tenericutes). Int. J. Syst. Bacteriol. 45:605-612.

17. Konai, M., E. A. Clark, and R. F. Whitcomb. 1992. Temperature ranges, growth optima, and growth rates of Spiroplasma (Spiroplasmataceae: class Mollicutes) species. Curr. Microbiol. 32:1-7.

18. Konai, M., R. F. Whitcomb, and M. Camp. 1994. Growth of spiroplasmas at the upper temperature range limit. IOM Lett. 3:527-528.

19. Konai, M., R. F. Whitcomb, F. E. French, J. G. Tully, D. L Rose, P. Carle, J. M. Bové, K. J. Hackett, R. B. Henegar, T. B. Clark, and D. L. Williamson. 1997. Spiroplasma litorale sp. nov., from tabanid flies (Tabanidae: Diptera) in the southeastern United States. Int. J. Syst. Bacteriol. 47:359-362.

20. Lewallen, B. E., and F. E. French. 1991. Spiroplasma (Mollicutes) from tabanids (Diptera: Tabanidae) April-May in southeastern Georgia, and laboratory transfer of spiroplasmas to tabanids. Ga. J. Sci. 49:20.

21. Markham, P. G., T. B. Clark, and R. F. Whitcomb. 1983. Culture techniques for spiroplasmas from arthropods. Methods Mycoplasmol. 2:217-223.

22. Minervino, J. S., and F. E. French. 1995. Spiroplasma (Entomoplasmatales) infection rates of tabanid fly hemolymph and viscera and extrahost survival. Ga. J. Sci. 53:22

23. Railey, P. B., and F. E. French. 1990. Laboratory transmission of Spiroplasma (Mollicutes) to Tabanidae (Diptera). Ga. J. Sci. 48:19.

24. Rose, D. L., J. G. Tully, J. M. Bové, and R. F. Whitcomb. 1993. A test for measuring growth responses of mollicutes to serum and polyoxyethylene sorbitan. Int. J. Syst. Bacteriol. 43:527-532.

25. Tully, J. G. 1983. Cloning and filtration techniques for mycoplasmas. Methods Mycoplasmol. 1:173-177.

26. Tully, J. G. 1996. Determination of cholesterol and polyoxyethylene growth requirements of mollicutes, p. 381-389. In S. Razin and J. G. Tully (ed.), Molecular and diagnostic procedures in mycoplasmology, vol. 1. Academic Press, San Diego, Calif.

27. Tully, J. G., J. M. Bové, F. Laigret, and R. F. Whitcomb. 1993. Revised taxonomy of the class Mollicutes: proposed elevation of a monophyletic cluster of arthropod-associated mollicutes to ordinal rank (Entomoplasma tales ord. nov.), with provision for familial rank to separate species with nonhelical morphology (Entomoplasmataceae fam. nov.) from helical species (Spiroplasmataceae), and emended descriptions of the order Mycoplasmatales, family Mycoplasmataceae. Int. J. Syst. Bacteriol. 43:378-385.

28. Tully, J. G., and S. Razin (ed.). 1996. Molecular and diagnostic procedures in mycoplasmology, vol. 2, p. 460-462. Academic Press, San Diego, Calif.

29. Tully, J. G., D. L. Rose, E. Clark, P. Carle, J. M. Bové, R. B. Henegar, R. F. Whitcomb, D. E. Colflesh, and D. L. Williamson. 1987. Revised group classification of the genus Spiroplasma (class Mollicutes), with proposed new groups XII to XXIII. Int. J. Syst. Bacteriol. 37:357-364.

30. Tully, J. G., and R. F. Whitcomb. 1991. The genus Spiroplasma, p. 1960 1980. In A. Balows, H. G. Trüper, M. Dworkin, W. Harder, and K.-H Schleifer (ed.), The prokaryotes, 2nd ed., vol. II. Springer-Verlag, New York, N.Y.

31. Wedincamp, J., Jr., F. E. French, R. F. Whitcomb, and R. Henegar. 1996 Spiroplasmas and entomoplasmas (Procaryotae: Mollicutes) associated with tabanids (Diptera: Tabanidae) and fireflies (Coleoptera: Lampyridae). J. Invertebr. Pathol. 68:183-186.

32. Whitcomb, R. F. 1983. Culture media for spiroplasmas. Methods Mycoplasmol. 1:147-158.

33. Whitcomb, R. F., F. E. French, E. A. Clark, and R. B. Henegar. Unpublished data.

34. Whitcomb, R. F., F. E. French, J. G. Tully, G. E. Gasparich, D. L. Rose, P. Carle, J. M. Bové, R. B. Henegar, M. Konai, K. J. Hackett, J. R. Adams, T. B. Clark, and D. L. Williamson. 1997. Spiroplasma chrysopicola sp. nov., Spiroplasma gladiatoris sp. nov., Spiroplasma helicoides sp. nov., and Spiroplasma tabanidicola sp. nov., from tabanid (Tabanidae: Diptera) flies. Int. J. Syst. Bacteriol. 47:713-719.

35. Whitcomb, R. F., G. Gasparich, F. E. French, J. G. Tully, D. L. Rose, P. Carle, J. M. Bové, R. B. Henegar, M. Konai, K. J. Hackett, J. R. Adams, T. B. Clark, and D. L. Williamson. 1996. Spiroplasma syrphidicola $\mathrm{sp}$. nov., from a syrphid (Diptera: Syrphidae) fly. Int. J. Syst. Bacteriol. 46:797-801.

36. Whitcomb, R. F., K. J. Hackett, J. G. Tully, E. A. Clark, F. E. French, R. B. Henegar, D. L. Rose, and A. G. Wagner. 1990. Tabanid spiroplasmas as a model for mollicute biogeography. Zentralbl. Bakteriol. Suppl. 20:931-933.

37. Whitcomb, R. F., D. L. Williamson, J. M. Bové, F. E. French, M. Konai, G. Gasparich, M. Abalain-Colloc, C. Saillard, C. Chastel, E. A. Clark, P. Carle, D. L. Rose, R. B. Henegar, and K. J. Hackett. 1992. Revised classification of spiroplasmas. IOM Lett. 2:134.

38. Williamson, D. L. 1983. Specialized electron microscopic techniques for spiroplasmas in plant and insect tissues. Methods Mycoplasmol. 1:71-76.

39. Williamson, D. L., J. G. Tully, and R. F. Whitcomb. 1979. Serological relationships of spiroplasmas as shown by combined deformation and metabolism inhibition tests. Int. J. Syst. Bacteriol. 29:345-351.

40. Williamson, D. L., J. G. Tully, and R. F. Whitcomb. 1989. The genus Spiroplasma, p. 71-111. In R. F. Whitcomb and J. G. Tully (ed.), The mycoplasmas, vol. 5. Academic Press, New York, N.Y.

41. Williamson, D. L., R. F. Whitcomb, and J. G. Tully. 1979. The spiroplasma deformation test, a new serological method. Curr. Microbiol. 1:203-207. 